\title{
Development of the Method to Produce Functionally Active Recombinant Streptavidin in Escherichia coli Cells
}

\author{
Eugenia E. Bashmakova*, \\ Alexander N. Kudryavtsev and Ludmila A. Frank \\ Institute of Biophysics SB RAS \\ $F R C$ «Krasnoyarsk Science Center SB RAS» \\ Krasnoyarsk, Russian Federation
}

Received 30.12.2019, received in revised form 25.03.2020, accepted 23.04.2020

\begin{abstract}
Streptavidin is a homotetrameric protein produced by Streptomyces avidinii, each subunit of which binds biotin (vitamin $\mathrm{H}$ ), forming a stable complex $\left(\mathrm{Kd}=10^{-15} \mathrm{M}\right)$. Streptavidin-biotin coreaction is widely used in analytical systems, for targeted delivery of compounds, for affinity purification, etc. The aim of this study was to develop a rational technique to produce functionally active recombinant streptavidin. Recombinant Escherichia coli strains producing minimal core and full-sized streptavidin variants were obtained. The E. coli BL21 Codon Plus (DE3) RIPL, as host cells, and the pET19b plasmid carrying gene of minimally-sized core (miniSAV) or full-sized (SAV) streptavidin were used. Synthesis of miniSAV results in its localization as insoluble inclusion bodies. Denatured miniSAV yield was $130 \mathrm{mg}$ per liter of $E$. coli culture. The renaturation gives only $10-$ $15 \%$ of the functionally active protein. Full-sized streptavidin localizes in the cytoplasm in a soluble state, but its toxicity causes low yield of the protein (10-13 mg per liter of the culture). The induction of SAV synthesis at the end of the logarithmic stage of cell growth was found to increase the yield of SAV approximately 2 -fold. The yield of functionally active protein was $30 \mathrm{mg}$ per liter culture. SAV was produced practically in individual state after affine chromatography on 2-iminobiotin agarose. One molecule of full-sized streptavidin bound 3.9 biotin molecules as was shown by colorimetric analysis using HABA (4-hydroxyazobenzene-2-carboxylic acid). Both streptavidins form sandwichtype complexes with biotinylated molecules in solid-phase microassay conditions. E. coli BL21 Codon Plus (DE3) RIPL/pET19bSAV strain was stable during storage with $20 \%$ glycerol at $-70{ }^{\circ} \mathrm{C}$, which was shown by repeated two-year reseeding. The streptavidin producing strain (E. coli BL21 Codon Plus (DE3) RIPL/pET19bSAV) is deposited in the Collection for extremophile microorganisms and type
\end{abstract}

(C) Siberian Federal University. All rights reserved

This work is licensed under a Creative Commons Attribution-NonCommercial 4.0 International License (CC BY-NC 4.0).

* Corresponding author E-mail address: bashmakovae@ibp.ru

ORCID: 0000-0002-8951-8599 (Bashmakova E.); 0000-0003-0034-1879 (Kudryavtsev A.); 0000-0003-4462-1944 (Frank L.) 
cultures (Institute of Chemical Biology and Fundamental Medicine SB RAS, Novosibirsk), No. 3505. The method for producing functionally active recombinant streptavidin developed in this study ensures its availability for biotechnological research.

Keywords: recombinant streptavidin, E. coli protein-producing strain, microanalysis.

\title{
Разработка способа получения
}

\section{функционально активного}

рекомбинантного стрептавидина

\section{в клетках Escherichia coli}

\author{
Е.Е. Башмакова, А.Н. Кудрявцев, Л.А. Франк \\ Институт биофизики СО РАН \\ ФИЦ «Красноярский научный изентр СО РАН» \\ Российская Федерация, Красноярск
}

\begin{abstract}
Аннотация. Стрептавидин - гомотетрамерный белок, продуцируемый Streptomyces avidinii, каждая субъединица которого связывает биотин (витамин Н) с образованием стабильного комплекса $\left(\mathrm{Kd}=10^{-15} \mathrm{M}\right)$. Стрептавидин-биотиновое взаимодействие используют в аналитических системах, для адресной доставки соединений, для аффинной очистки веществ и т.д. Цель данного исследования - разработать рациональный способ получения рекомбинантного функционально активного стрептавидина. Сконструированы штаммы Esherihia coli - продуценты минимального корового и полноразмерного вариантов стрептавидина с использованием одной и той же экспрессирующей системы - E. coli BL21 Codon plus (DE3) RIPL в качестве клетокхозяев и плазмиды pET19b, несущей ген минимального (miniSAV) или полноразмерного (SAV) стрептавидина. Экспрессия miniSAV сопровождается его локализацией в $E$. coli в виде нерастворимых телец включения. С 1 л культуры было получено 130 мг высокоочищенного денатурированного белка. Выход функционально активного белка после рефолдинга составил 1015 \%. Полноразмерный стрептавидин синтезируется в растворе цитоплазмы, но его токсичность обусловливает низкий выход (10-13 мг с 1 л культуры) этого белка при стандартных условиях культивирования. Установлено, что индукция синтеза SAV в конце логарифмической фазы роста культуры обеспечивает выход функционально активного белка 30 мг с 1 л культуры. Препарат высокоочищенного SAV получали одностадийной аффинной хроматографией на 2-иминобиотинагарозе. Колориметрическим анализом с использованием красителя НАBA (4-гидроксиазобензол2-карбоновой кислоты) определено, что одна молекула SAV связывает 3,9 молекулы биотина. Штамм E. coli BL21 Codon Plus (DE3) RIPL/pET19bSAV стабилен при хранении с добавлением
\end{abstract}


20 \% глицерина при минус $70{ }^{\circ} \mathrm{C}$, что подтверждено многократными пересевами в течение 2 лет. Показана применимость обоих вариантов стрептавидина для образования высокоспецифичных комплексов между биотинилированными молекулами в условиях твердофазного микроанализа сэндвич-типа. Штамм-продуцент рекомбинантного стрептавидина (E. coli BL21 CodonPlus (DE3) RIPL/pET19bSAV) хранится в коллекции экстремофильных и типовых культур ИХБФМ СО РАН (Новосибирск), № КЭМТК 3505. Разработанный способ получения рекомбинантного функционально активного стрептавидина обеспечивает его доступность для биотехнологических исследований.

Ключевые слова: рекомбинантный стрептавидин, штамм-продуцент E. coli, микроанализ.

Цитирование: Башмакова, Е.Е. Разработка способа получения функционально активного рекомбинантного стрептавидина в клетках Escherichia coli / Е.Е. Башмакова, А.Н. Кудрявцев, Л.А. Франк // Журн. Сиб. федер. ун-та. Биология, 2020. 13(2). С. 218-229. DOI: 10.17516/1997-1389-0324

\section{Введение}

Стрептавидин - это гомотетрамерный белок, продуцируемый Streptomyces avidinii, каждая субъединица которого связывает биотин (витамин Н). Образующийся при этом комплекс обладает уникальной для нековалентных соединений стабильностью $\left(\mathrm{Kd}=10^{-15} \mathrm{M}\right)$. Благодаря этому стрептавидин-биотиновое взаимодействие широко используют в различных аналитических системах, для адресной доставки соединений, для аффинной очистки целевых соединений и т.д. (см., напр., обзор Dundas et al., 2013). Стрептавидин всесторонне изучен: определены его физико-химические свойства, пространственная структура интактного белка и его многочисленных генетических вариантов, а также комплексов с биотином. Коммерчески доступен сам белок и множество его производных - химических конъюгатов и генетических гибридов с другими белками, а также биотин и его производные. Уникальные свойства этой системы вызывают постоянный интерес, в большей степени прикладной, и публикации о получении новых вариантов стрептавидина, разработке новых продуцентов и способов выделения этих белков появляются регулярно. В литературе с 1990-х гг. описаны бактериальные продуценты, в которых накопление стрептавидина происходит в виде нерастворимых телец включения (см., напр., Sano \& Cantor, 1990; Humbert et al., 2005; Jouybari et al., 2018; Chua et al., 2018). Этот подход обеспечивает получение большого количества денатурированного белка, однако осложняется необходимостью проведения рефолдинга, который происходит с низким выходом функционально активного белка. Предложены варианты получения рекомбинантного стрептавидина с транслокацией в периплазматическое пространство клеток (Veiko et al., 1999) или в ростовую среду (Noda et al., 2015). Для выделения целевого белка в этих случаях необходимы дополнительные стадии либо фракционирования клеточной биомассы, либо его осаждения из ростовой среды с последующей денатурацией.

В некоторых работах стрептавидин получают в виде гибридного белка со вспомогательными пептидами, обеспечивающими его растворимость в цитоплазме, а также одностадийную аффинную очистку (Schmidt \& Skerra, 1994; Gallizia et al., 1998; Sørensen 
et al., 2003; Humbert et al., 2008; Noda et al., 2015). Анализ литературных данных по получению рекомбинантного стрептавидина выявляет довольно пеструю картину, когда авторы получают разные варианты стрептавидина с помощью разных экспрессирующих конструкций, используют различные условия денатурации-рефолдинга целевого белка, иногда указывают на возникающие противоречия с ранее опубликованными исследованиями и т.д. Все это не позволяет выбрать среди известных способов получения этого белка наиболее оптимальный.

Целью нашего исследования было разработать рациональный способ получения рекомбинантного функционально активного стрептавидина, для чего получить рекомбинантный штамм Escherichia coli, обеспечивающий синтез белка с хорошей продуктивностью и простой способ его выделения и очистки. В ходе работ были рассмотрены способы получения двух вариантов стрептавидина - минимального корового и полноразмерного, отличающихся по размеру, но при этом, по литературным данным, обладающих близкой функциональной активностью.

\section{Материалы и методы}

\section{материальь}

Высокоочищенный $\mathrm{Ca}^{2+}$-активируемый фотопротеин обелин получали так, как описано ранее (Illarionov et al., 2000). Биотинилированные производные бычьего сывороточного альбумина (BSA-bio) и обелина (bio-Obe) получали реакцией с 20- и 5-молярным избытком сукцинимидного производного биотина (Pierce, США) с последующим удалением избытка реагента гель-фильтрацией (Frank, Vysotski, 1997). Олигонуклеотиды синтезированы ООО Биосан (Россия). В работе использовали бычий сывороточный альбумин (Sigma, США), d-биотин, 4-гидроксиазобензол-2-карбоновую кислоту (НАВА) (Pierce, США). Все вспомогательные реагенты отечественного производства (соли, кислоты, щелочи) были аналитической или химической чистоты.

Белковый состав образцов анализировали с помощью вертикального гельэлектрофореза в 15\%-ном полиакриламидном геле в денатурирующих условиях (Laemmli, 1970). Анализ гелей проводили в камере AlphaImager (AlphaInnotech, США).

Концентрацию стрептавидина определяли колориметрически по методу, описанному в (Green, 1970), либо спектрофотометрически на длине волны 280 нм, пользуясь значением коэффициента экстинкции $\mathrm{E}^{0,1 \%}=3,4$ (Schmidt \& Skerra, 1994).

Конструирование плазмидных ДНК pET19b-SAV u pET19b-miniSAV

с последовательностями, кодирующими полноразмерньий (A) или минимальнылй коровылй (Б) стрептавидинь соответственно

(A) Штамм Streptomyces avidinii (AC865, Российская национальная коллекция промышленных микроорганизмов) высевали в жидкую среду (10 г/л пептона, 5 г/л NaCl, $\mathrm{pH}=7,2)$ и культивировали 3 суток при $28{ }^{\circ} \mathrm{C}$. Клетки осаждали центрифугированием (4000 g, $\left.4{ }^{\circ} \mathrm{C}\right)$. Хромосомную ДНК S. avidinii выделяли с помощью набора GeneJET Plasmid Miniprep Kit (Thermo Fisher Scientific) и использовали в качестве матрицы для ПЦР.

Фрагмент ДНК, кодирующий полноразмерный стрептавидин без лидерного пептида (480 п.о.) с сайтами рестрикции 5'-(NcoI) и 3'(Xhol), получали с помощью ПЦР с использованием Pfu-полимеразы (СибЭнзим, Россия) и следующих праймеров:

Up 5'-CGCTCCATGGACCCCTCCAAGG ACTC-3'; 


\section{Dn 5'-CGGGCTCGAGCTACTGCTGAA} CGGCG-3'. Синтезированный фрагмент клонировали в вектор pET-19b (Novagen) по соответствующим сайтам с получением плазмиды pET19b-SAV.

(Б) В качестве матрицы для получения гена минимального стрептавидина использовали плазмиду pETSAV (Bashmakova et al., 2017). Фрагмент ДНК, кодирующий минимальный стрептавидин (376 п.о.) с сайтами рестрикции 5'-(NcoI) и 3'-(XhoI), получали с помощью ПЦР с использованием Pfuполимеразы и следующих праймеров:

Up 5'-CGCTCCATGGGCATCACCGGC ACCTGGTAC-3';

Dn 5'-CGGGCTCGAGTCACACCTTG GTGAAGGTGTCGTGG-3'. Синтезированный фрагмент клонировали в вектор рЕТ-19b (Novagen) по соответствующим сайтам с получением плазмиды pET19b-miniSAV.

Последовательность клонированных фрагментов подтверждена секвенированием (ЦКП «Геномика» СО РАН, Россия).

Биосинтез стрептавидина

клетками E. coli

Клетки E. coli BL21 Codon Plus (DE3) RIPL, далее - RIPL (Novagen), трансформированные pET19b-SAV, культивировали в LB-среде, содержащей ампициллин (200 мг/л), с активным перемешиванием (220 об/мин, Excella E25R Shaker, Eppendorf, Германия) при $37{ }^{\circ} \mathrm{C}$. Синтез целевого белка инициировали добавлением 1 мМ изопропил- $\beta$-D-1-тиогалактопиранозида (ИПТГ) при определенном значении оптической плотности культуры $\left(\mathrm{OD}_{600}\right)$ и продолжали культивирование в тех же условиях еще 4 ч. За накоплением стрептавидина следили с помощью электрофореза, анализируя белковый состав клеток в периодически отбираемых пробах.
Рекомбинантные клетки RIPL/pET19bminiSAV культивировали в аналогичных условиях; индукцию синтеза минимального корового стрептавидина проводили при значении $\mathrm{OD}_{600}$ культуры, равном 0,8. Далее культивировали в тех же условиях еще 4 ч.

Выделение и очистка полноразмерного cтрептавидина (SAV)

Клетки E. coli осаждали центрифугированием (4000 g, 15 мин, $\left.4{ }^{\circ} \mathrm{C}\right)$. Осадок ресуспендировали в буфере А $(0,5 \mathrm{M} \mathrm{NaCl}$, 50 мМ $\left.\mathrm{Na}_{2} \mathrm{CO}_{3}, \mathrm{pH} 11,0\right)$ и разрушали с помощью ультразвукового дезинтегратора при охлаждении льдом. Полученную суспензию центрифугировали (10000 g, 10 мин, $\left.4{ }^{\circ} \mathrm{C}\right)$, осадок отбрасывали. Супернатант наносили на колонку, содержащую 2-иминобиотин агарозу (Pierce, США), уравновешенную буфером А, промывали пятикратным объемом того же буфера, а затем двукратным объемом буфера Б (1 M NaCl в 0,1 M K-Na-фосфатном буфере, pH 7,0 - ФБ). Элюцию стрептавидина проводили раствором 50 мМ $\mathrm{CH}_{3} \mathrm{COOH}, \mathrm{pH}$ 4,0 , элюат немедленно нейтрализовали добавлением 1 М Трис-HCl, pH 7,5. Фракции, содержащие стрептавидин, объединяли, переводили диализом в 5 мМ Трис-HCl, $\mathrm{pH} 7,5$, лиофилизировали и хранили при минус $20^{\circ} \mathrm{C}$.

\section{Выделение и очистка рекомбинантного}

минимального корового

стрептавидина (miniSAV)

Клетки осаждали и дезинтегрировали, как описано выше. После центрифугирования супернатант отбрасывали, а осадок растворяли в 20 мМ Трис-HCl $\mathrm{pH}$ 7,0, содержащим $6 \mathrm{M}$ мочевину, и наносили на колонку DEAE Sepharose FF (GE-Healthcare, США), уравновешенную тем же раствором. Белки элюировали градиентом $\mathrm{NaOAc}(0-0,5 \mathrm{M})$ в том же буфере. Фракции, содержащие целевой белок, 
объединяли. Аликвоты, содержащие очищенный минимальный стрептавидин, диализовали против: а) 10 мМ Трис-HCl pH 7,0; б) 20 мМ K-Na-фосфатного буфера, pH 8,0; в) 0,2 М $\mathrm{NaHCO}_{3}$, pH 9,8. Выпавший во всех случаях осадок, содержащий до $90 \%$ miniSAV, отделяли центрифугированием, супернатант использовали для дальнейшей работы. Повторным растворением осадка и диализом получали еще около 10 \% активного miniSAV.

Модельный твердофазный микроанализ

В лунки непрозрачного планшета (Costar, США) вносили по 100 мкл раствора BSA-bio $(100 ; 33,3 ; 11,1 ; 3,7 ; 1,2 ; 0,41 ; 0,14 ; 0$ нг/мл, ФБ) и инкубировали 12 ч при $8{ }^{\circ} \mathrm{C}$. После промывки (ФБ, 0,1 \% Tween 20, 5 мМ ЭДТА) в лунки вносили по 110 мкл 1\%-го раствора бычьего сывороточного альбумина в ФБ, инкубировали 1 ч при $37{ }^{\circ} \mathrm{C}$, затем промывали. Далее в лунки вносили по 100 мкл раствора полученных образцов стрептавидина (ФБ, 1 мкг/мл), инкубировали со встряхиванием (350 об/мин, Thermomixer C, Eppendorf, Германия) в течение 1 ч при $37^{\circ} \mathrm{C}$, затем промывали и вносили по 100 мкл раствора bio-Obe (0,2 мкг/мл в 20 мМ Трис-HCl, pH 7,0, 0,15 M NaCl, 5 мМ ЭДТА). После инкубирования со встряхиванием в течение 1 ч при $23{ }^{\circ} \mathrm{C}$ и промывки измеряли интегральный биолюминесцентный сигнал связавшегося обелина с помощью планшетного люминометра Mithras LB 940 (Berthold, Германия) сразу после впрыска 100 мкл раствора $\mathrm{CaCl}_{2}(0,1 \mathrm{M}$ в 0,1 М Трис$\mathrm{HCl}, \mathrm{pH} 8,8)$ в течение 3 с. Усредненный сигнал от контрольных лунок (с ФБ) вычитали от сигналов рабочих лунок.

\section{Результаты и обсуждение}

Современный рынок предлагает препараты стрептавидина, его аналогов и конъюгатов с другими молекулами, в подавляющем большинстве импортного производства, стоимость которых достаточно высока. Стрептавидин-биотиновая система благодаря своим уникальным свойствам нашла широкое применение как в фундаментальных, так и в прикладных исследованиях. В этом аспекте важным является наличие доступного отечественного препарата этого белка. Природный стрептавидин $S$. avidinii в результате посттрансляционного процессинга может находиться в различных укороченных вариантах, каждый из которых обладает биоспецифической активностью (Bayer et al., 1989). Аминокислотная последовательность нативного стрептавидина (183 а.о., рис. 1) включает лидерный пептид (24 а.о.), обеспечивающий секрецию белка, и полноразмерный стрептавидин (159 а.o., pdb ID: 1STP). Укороченный в результате протеолиза стрептавидин A13S139 (127 а.о.) называется нативным коровым, иногда «зрелым». Показано, что коровый стрептавидин более стабилен, и, вероятно, многие коммерческие препараты этого белка являются продуктами частичного протеолиза полноразмерного стрептавидина.

Минимальный коровый вариант стрептавидина (G16-V133, 119 а.о.), состоящий только из аминокислот $\beta$-цилиндра, был получен Т. Sano с соавторами (Sano et al., 1995). Ими показано, что полное удаление концевых аминокислотных остатков приводит к повышению структурной стабильности белка и его способности к связыванию биотинсодержащих молекул.

На первом этапе нами получен штамм E. coli - продуцент минимального корового стрептавидина (miniSAV) как наиболее стабильного варианта функционального стрептавидина минимального размера (Sano et al., 1995). Рекомбинантные клетки, трансформированные плазмидой $\mathrm{pET19b-miniSAV,} \mathrm{куль-}$ тивировали до плотности $\mathrm{OD}_{600}=0,8$ и иници- 


\section{SAV (159 a.o.)}

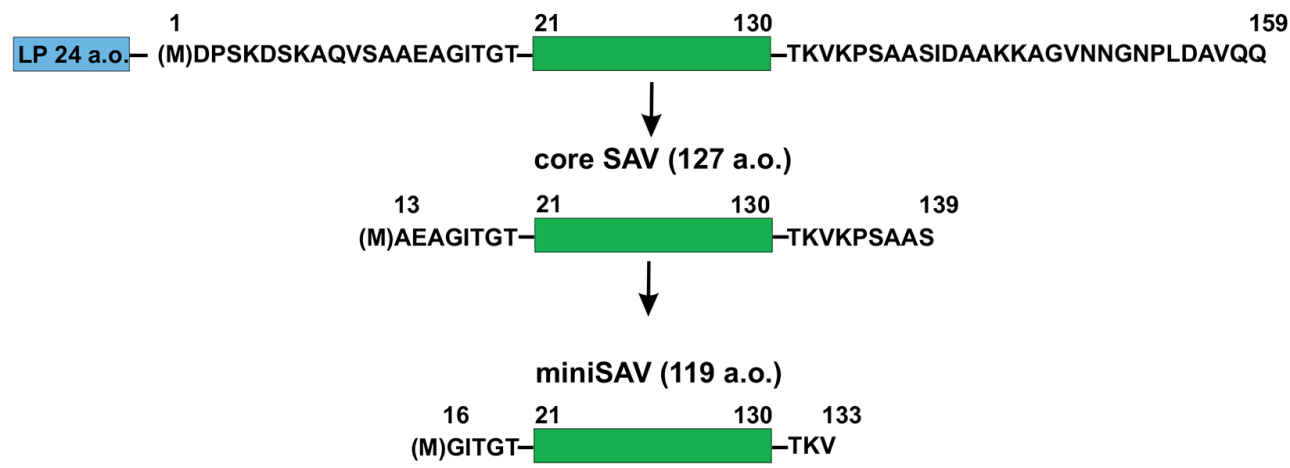

Рис. 1. Аминокислотная последовательность нативного стрептавидина: лидерный пептид (24 а.о., выделен синим), полноразмерный белок (SAV, 1-159), нативный коровый фрагмент (coresAV, 13-139 а.о.), минимальный коровый фрагмент (miniSAV, 16-133 а.о.). Зеленым выделен константный участок белка. В скобках показаны метионины, введенные при конструировании плазмид pET19b-SAV, и pET19b-miniSAV. a.о. - аминокислотные остатки

Fig. 1. Amino acid sequence of native streptavidin: leader peptide (24 a.a., highlighted in blue), full-sized protein (SAV, 1-159), core streptavidin (coreSAV, 13-139 a.a.), minimal core fragment (miniSAV, 16-133 a.a.). Constant protein fragment is highlighted in green. Methionines introduced during construction of pET19b-SAV and pET19b-miniSAV plasmids are given in parentheses. a.o. - amino acid residues

ировали синтез стрептавидина добавлением ИПТГ. За ходом накопления стрептавидина и его распределением в клетках следили с помощью гель-электрофореза (рис. 2a). Чеpeз 1 ч после индукции появляется полоса нового белка с мол. массой около 13 кДа, близкой к расчетному значению массы мономера miniSAV. Вклад этой полосы через 1, 2,5 и 4 ч составил 9, 14 и $25 \%$ соответственно. Практически весь белок был аккумулирован в тельцах включения (рис. $2 a$ ), из которых его перевели в буфер, содержащий 6М мочевину, и очистили хроматографически. Выход полученного денатурированного miniSAV высокой степени очистки (99 \%) составил 130 мг/л культуры. Функционально активный белок получали с помощью диализа против буферных растворов различного состава (см. экспериментальную часть). При этом во всех экспериментах 85-90 \% белка вновь выпадали в осадок, который отделяли центрифугированием, белок в супернатанте использовали для работы далее. Способность miniSAV об- разовывать специфичный комплекс сэндвичтипа с биотинилированными молекулами, стабильный в условиях твердофазного микроанализа, исследовали в модельном эксперименте (см. схему на рис. 3 , сверху).

В качестве репортера использовали $\mathrm{Ca}^{2+}$-регулируемый фотопротеин обелин, молекула которого представляет собой фермент-субстратный комплекс апобелка и предокисленного субстрата - пероксицелентеразина (Frank, 2010). Присоединение ионов $\mathrm{Ca}^{2+}$ вызывает яркую вспышку голубого света, интенсивность которого при насыщающей концентрации $\mathrm{Ca}^{2+}$ прямо пропорциональна содержанию фотопротеина. Обелин и другие фотопротеины широко используются в качестве удобного высокочувствительного инструмента в различных аналитических системах (Frank, 2015). На поверхности непрозрачного планшета последовательным инкубированием растворов белков получали комплексы между биотинилированным производным бычьего сывороточного альбумина 


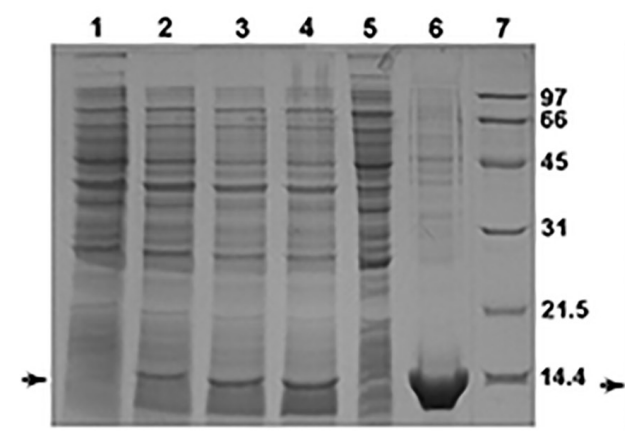

a)

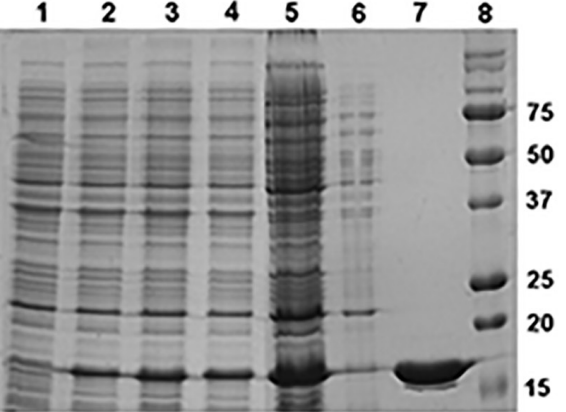

б)

Рис. 2. (a) Электрофоретический анализ образцов при выделении miniSAV: 1 - тотальные белки клеток RIPL/pET19b-miniSAV до индукции; 2-4 - тотальные клеточные белки через 1, 3, 5 ч после индукции, образцы нормированы по плотности культуры; 5 -цитоплазматические белки; 6 - осадок телец включения (раствор в 6 М мочевине); 7 - маркерные белки (BioRad, SDS-Page standards Low Range); (б) анализ образцов при выделении SAV: 1-6, то же, что и в случае (a); 7 - полноразмерный стрептавидин после хроматографической очистки; 8 - маркерные белки (BioRad, Precision Plus Protein Dual Xtra Standards). Молекулярная масса стандартных белков в кДа показана числами справа. Электрофорез проводили в 15\%-ном полиакриламидном геле в денатурирующих условиях, окрашивание Coomassie blue. Стрелками показаны полосы стрептавидинов

Fig. 2. (a) SDS-PAGE analysis of samples during minimal core streptavidin production: 1 - whole cell lysates before IPTG induction; 2-4 whole cell lysates 1, 3, and $5 \mathrm{~h}$ after induction, respectively, samples are normalized against cell density; 5 - cytoplasmic proteins; 6-6 M urea extract of inclusion bodies; 7 - marker proteins (BioRad, SDS-Page standards Low Range). (б) The analysis of samples during full-sized streptavidin production: 1-6 - samples like in (a); 7 - SAV sample after chromatographic purification, 8 - marker proteins (BioRad, Precision Plus Protein Dual Xtra Standards). Molecular masses of standard proteins are shown by numbers on the right side. $15 \%$ polyacrylamide gels stained with Coomassie blue. Arrows show streptavidin bands

(BSA-bio), miniSAV и биотинилированным производным обелина (bio-Obe). Их обнаруживали по биолюминесцентному сигналу обелина при добавлении раствора $\mathrm{CaCl}_{2}$. $\mathrm{Be}$ личина сигнала прямо пропорциональна количеству сорбированного BSA-bio во всем диапазоне его концентраций (рис. 3).

Этот результат показывает, что полученный нами miniSAV представляет собой стабильный олигомерный белок, способный присоединять одновременно как минимум две биотинилированные молекулы с образованием комплекса сэндвич-типа и может быть использован для этой цели в твердофазном микроанализе.

Синтез рекомбинантного полноразмерного стрептавидина (SAV) осуществляли инкубированием рекомбинантных клеток E. coli, трансформированных плазмидой
pET19b-SAV. За накоплением белка, его локализацией в клетках и чистотой полученного после аффинной хроматографии препарата следили с помощью гель-электрофореза (рис. 2б). Видно, что через 1 ч после индукции (при $\left.\mathrm{OD}_{600}=0,9\right)$ появляется полоса нового белка с мол. массой около 16 кДа, близкой к расчетному значению массы мономера полноразмерного стрептавидина. Вклад этой полосы от всех белков через 1, 3, и 5 ч составил 9, 13 и $13 \%$ соответственно. При этом основное количество белка находится в растворимой фракции (рис. 2б). После хроматографии из клеточного лизата был получен препарат белка высокой степени очистки, выход которого составлял всего 11-13 мг с 1 л культуры. Очевидно, это связано с показанной ранее токсичностью стрептавидина для клеток E. coli. Мы предположили, что более поздняя индукция 


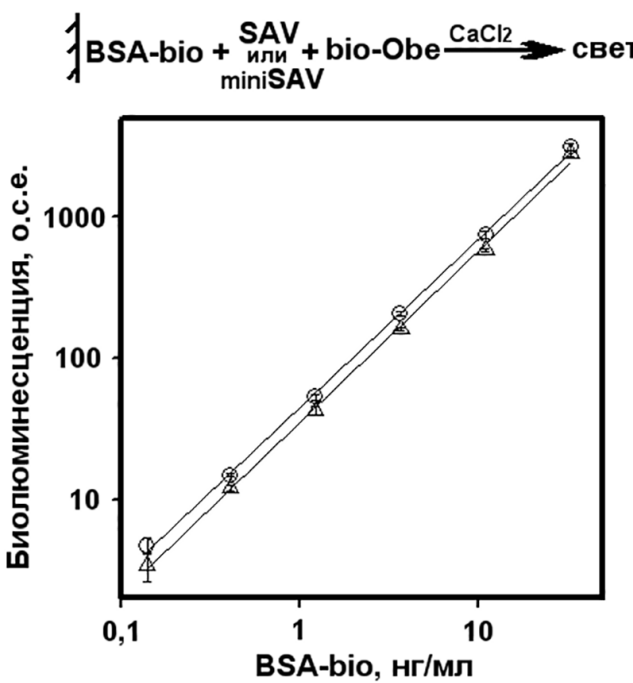

Рис. 3. Применение miniSAV (-о-) и SAV $(-\Delta-)$ в твердофазном биолюминесцентном микроанализе сэндвич-типа. Каждая точка среднее значение от трех независимых измерений \pm среднеквадратичное отклонение. о.с.е.относительные световые единицы

Fig. 3. Use of miniSAV (-०-) and SAV (- $\left.\Delta^{-}\right)$in a solidphase bioluminescent sandwich-type microanalysis. Each point is the average of 3 independent measurements $\pm \mathrm{SD}$

может увеличить выход стрептавидина за счет увеличения количества клеток в момент добавления ИПТГ. При параллельном культивировании трех образцов культуры в одинаковых условиях синтез индуцировали при оптической плотности $\mathrm{OD}_{600}=0,9,1,9$ или 2,8 и культивировали еще 4 ч.

С началом синтеза стрептавидина рост клеток резко замедляется по сравнению с ростом тех же клеток без индукции (рис. 4). В таблице приведен выход белка в каждом случае. Оказалось, что индукция синтеза стрептавидина при $\mathrm{OD}_{600}=1,9$ всего на полчаса позже, чем при $\mathrm{OD}_{600}=0,9$, увеличивает продукцию целевого белка более чем в 2 раза, до $28 \pm 1,4$ мг/л. В случае еще более поздней индукции, при $\mathrm{OD}_{600}=2,8$, когда культура находится в стадии замедленного роста, выход белка не увеличился и составил $27 \pm 2,3$ мг/л. При этом небольшое количество белка было обнаружено в культуральной среде, очевидно, из-за начавшегося лизиса клеток. Как видно из кинетики роста культуры (рис. 4), после индукции рост останавливается примерно через 2 ч, после чего продолжать культивирование нецелесообразно.

Колориметрическим методом на основе комплексов с НАBA (Green, 1970) показано, что моль SAV связывает 3,9 моля биотина. В модельном твердофазном анализе полученный полноразмерный стрептавидин так же, как и минимальный коровый, образует комплексы между биотинилированными БСА и обелином (рис. 3).

Таким образом, в поисках наиболее рационального способа получения рекомбинантного стрептавидина нами рассмотрены два его варианта - miniSAV и SAV. Быстрое накопление miniSAV приводит к его осаждению в виде нерастворимых телец включения. Несмотря на очевидные преимущества

Таблица. Результаты культивирования рекомбинантных клеток RIPL/pET19b-SAV

Table. Results of cultivation of the recombinant RIPL/pET19b-SAV cells

\begin{tabular}{|c|c|c|c|}
\hline $\begin{array}{c}\text { Индукция при } \\
\text { OD }_{600}\end{array}$ & $\begin{array}{c}\text { Количество полученного } \\
\text { стрептавидина }{ }^{1}, \text { мг/л культуры }\end{array}$ & $\begin{array}{c}\text { Количество биомассы, } \\
\text { сырой вес, г }\end{array}$ & $\begin{array}{c}\text { Общее время } \\
\text { культивирования, ч }\end{array}$ \\
\hline 0,9 & $15,6 \pm 1,2$ & $5,2 \pm 0,9$ & 6,75 \\
\hline 1,9 & $28,0 \pm 1,4$ & $6,7 \pm 0,3$ & 7,25 \\
\hline 2,8 & $27,0 \pm 2,3$ & $6,3 \pm 0,2$ & 9 \\
\hline
\end{tabular}

${ }^{1}$ Хроматографически очищенный белок. 
такой экспрессии (в осадке белок находится в значительном количестве и практически индивидуальном виде; его легко отделять от остальных цитоплазматических белков центрифугированием; «вывод» белка из раствора цитоплазмы уменьшает вредное воздействие в случае его токсичности), она сопровождается серьезной проблемой фолдинга белка для восстановления его специфической активности. Предсказать локализацию рекомбинантного белка, как и найти оптимальные условия его фолдинга, не всегда удается. Так, ранее нами был получен ряд функционально активных рекомбинантных белков апофотопротеинов и люцифераз различных организмов, а также гибрид минимального корового стрептавидина с обелином локализованных в клетках E. coli исключительно в виде телец включения (см., напр.: Illarionov et al., 2000; Markova et al., 2004; Titushin et al., 2008; Markova et al., 2010; Bashmakova et al., 2017). В то же время суперэкспрессия бактериальной люциферазы Photobacterium leiognathi в рекомбинантных клетках E. coli RIPL вообще не сопровождается ее выпадением в осадок (неопубликованные данные). Рефолдинг полученного нами miniSAV с помощью часто используемого процесса диализа, к сожалению, обеспечивал низкий выход активного белка - 10-15 \% от исходного денатурированного белка.

Полноразмерный стрептавидин при получении с помощью аналогичной экспрессирующей системы аккумулируется в цитоплазме, что приводит к резкому снижению скорости роста клеток из-за его токсичности. Замедление клеточного метаболизма не позволяет накопить значительное количество целевого белка, однако индукция в стадии поздней логарифмической фазы роста увеличила его выход почти в 2 раза. Синтез белка в растворенном виде не создает проблемы фол-

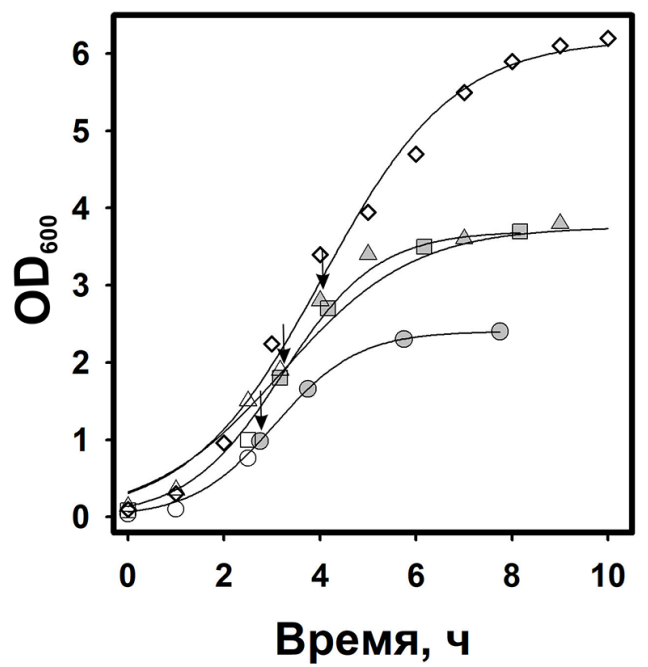

Рис. 4. Кинетика роста культуры E. coli RIPL/ pET19b-SAV: без ИПТГ-индукции $(-\diamond-), \quad$ c индукцией при оптической плотности $\mathrm{OD}_{600}=0,9$ (-о-), 1,9 (-口-), 2,8 (- $\Delta$-). Серые символы показывают значения $\mathrm{OD}_{600}$ после индукции. Стрелками показан момент добавления ИПТГ

Fig. 4. Kinetics of E. coli RIPL/pET19b-SAV culture growth: without IPTG-induction $(-\diamond-)$, with induction at a density of $\mathrm{OD}_{600}=0.9(-\circ-), 1.9(-\square-)$, and $2.8(-\Delta-)$. Gray symbols indicate the absorbance after induction. Arrows indicate the IPTG introduction

динга: его функциональная активность показана с помощью реакции с НАВА, а также в модельном микроанализе. Таким образом, получение полноразмерного стрептавидина предложенным способом обладает очевидными преимуществами: выход белка высокой очистки составляет около 30 мг с 1 л культуральной среды. Белок легко выделяется одностадийной хроматографией и обладает биоспецифической активностью, близкой таковой для природного белка. Клетки E. coli BL21 Codon Plus (DE3)/pET19b-SAV не теряют плазмиду при хранении в 20\%-ном глицерине при минус $70{ }^{\circ} \mathrm{C}$, что показано многократными пересевами в течение 2 лет. Штамм хранится в коллекции экстремофильных и типовых культур ИХБФМ СО РАН (Новосибирск), № КЭМТК 3505. 


\section{Список литературы / References}

Bashmakova E.E., Krasitskaya V.V., Kudryavtsev A.N., Grigorenko V.G., Frank L.A. (2017) Hybrid minimal core streptavidin-obelin as a versatile reporter for bioluminescence-based bioassay. Photochemistry \& Photobiology, 93(2): 548-552

Bayer E.A., Ben-Hur H., Hiller Y., Wilchek M. (1989) Postsecretory modifications of streptavidin. Biochemical Journal, 259(2): 369-376

Chua L.H., Tan S.C., Liew M.W.O. (2018) Process intensification of core streptavidin production through high-cell-density cultivation of recombinant E. coli and a temperature-based refolding method. Journal of Biotechnology, 276-277: 34-41

Dundas C.M., Demonte D., Park S. (2013) Streptavidin-biotin technology: improvements and innovations in chemical and biological applications. Applied Microbiology \& Biotechnology, 97(21): 9343-9353

Frank L.A., Vysotski E.S. (1997) Bioluminescent immunoassay of alphafetoprotein with $\mathrm{Ca}^{2+}$ activated photoprotein obelin. Bioluminescence and chemiluminescence. Molecular reporting with photons. Hastings J.W., Kricka L.J., Stanley P.E. (eds.) John Wiley \& Sons, Chichester, UK, p. 439-442

Frank L.A. (2010) $\mathrm{Ca}^{2+}$-regulated photoproteins: effective immunoassay reporters. Sensors, 10(12): $11287-11300$

Frank L.A. (2015) Creation of artificial luciferases to expand their analytical potential. Combinatorial Chemistry \& High Throughput Screening, 18(10): 919-929

Green N.M. (1970) Spectrophotometric determination of avidin and biotin. Methods in Enzymology, 18(A): 418-424

Gallizia A., de Lalla C., Nardone E., Santambrogio P., Brandazza A., Sidoli A., Arosio P. (1998) Production of a soluble and functional recombinant streptavidin in Escherichia coli. Protein Expression \& Purification, 14(2): 192-196

Humbert N., Zocchi A., Ward T.R. (2005) Electrophoretic behavior of streptavidin complexed to a biotinylated probe: a functional screening assay for biotin-binding proteins. Electrophoresis, 26(1): $47-52$

Humbert N., Schürmann P., Zocchi A., Neuhaus J.M., Ward T.R. (2008) High-yield production and purification of recombinant T7-tag mature streptavidin in glucose-stressed E. coli. Methods in Molecular Biology, 418: 101-110

Jouybari R.M., Sadeghi A., Khansarinejad B., Abbasian S.S., Abtahi H. (2018) Production of recombinant streptavidin and optimization of refolding conditions for recovery of biological activity. Reports of Biochemistry \& Molecular Biology, 6(2): 178-185

Illarionov B.A., Frank L.A., Illarionova V.A., Bondar V.S., Vysotski E.S., Blinks J.R. (2000) Recombinant obelin: Cloning and expression of cDNA, purification and characterization as a calcium indicator. Methods in Enzymology, 305: 223-249

Laemmli U.K. (1970) Cleavage of structural proteins during the assembly of the head of bacteriophage T4. Nature, 227(5259): 680-685

Markova S.V., Golz S., Frank L.A., Kalthof B., Vysotski E.S. (2004) Cloning and expression of cDNA for a luciferase from the marine copepod Metridia longa. Journal of Biological Chemistry, 279(5): 3212-3217 
Markova S.V., Burakova L.P., Frank L.A., Golz S., Korostileva K.A., Vysotski E.S. (2010) Greenfluorescent protein from the bioluminescent jellyfish Clytia gregaria cDNA cloning, expression, and characterization of novel recombinant protein. Photochemical \& Photobiological Sciences, 9(6): 757765

Noda S., Matsumoto T., Tanaka T., Kondo A. (2015) Secretory production of tetrameric native full-length streptavidin with thermostability using Streptomyces lividans as a host. Microbial Cell Factories, 14: 5

Sano T., Cantor C.R. (1990) Expression of a cloned streptavidin gene in Escherichia coli. Proceedings of the National Academy of Sciences of the United States of America, 87(1): 142-146

Sano T., Pandori M.W., Chen X., Smith C.L., Cantor C.R. (1995) Recombinant core streptavidins: a minimum-sized core streptavidin has enhanced structural stability and higher accessibility to biotinylated macromolecules. Journal of Biological Chemistry, 270(47): 28204-28209

Schmidt T.G.M., Skerra A. (1994) One-step affinity purification of bacterially produced proteins by means of the "Strep tag" and immobilized recombinant core streptavidin. Journal of Chromatography A, 676(2): 337-345

Sørensen H.P., Sperling-Petersen H.U., Mortensen K.K. (2003) A favorable solubility partner for the recombinant expression of streptavidin. Protein Expression and Purification, 32(2): 252-259

Titushin M.S., Markova S.V., Frank L.A., Malikova N.P., Stepanyuk G.A., Lee J., Vysotski E.S. (2008) Coelenterazine-binding protein of Renilla muelleri: cDNA cloning, overexpression, and characterization as a substrate of luciferase. Photochemical \& Photobiological Sciences, 7(2): 189-196

Veiko V.P., Gul'ko L.B., Okorokova N.A., D'yakov N.A., Debabov V.G. (1999) Cloning and expression of the streptavidin gene from Streptomyces avidinii in Escherichia coli and secretion of streptavidin by E. coli cells. Russian Journal of Bioorganic Chemistry, 25(3): 161-165 